\title{
Americans shooting themselves in the foot: the epidemiology of podiatric self-inflicted gunshot wounds in the United States
}

$\mathrm{T}$ he United States is home to about one third of all firearms worldwide, with 90 guns for every 100 American citizens. ${ }^{1}$ It is therefore perhaps not surprising that gunshot wounds (GSWs) are among the leading causes of injury in the US., ${ }^{2,3}$ The statistics indicate that $93 \%$ of the wounded are men, $56 \%$ are unemployed, and $56 \%$ tested positive for drugs or alcohol after the incident. ${ }^{4-6}$ As the incidence of GSWs is increasing, epidemiological studies that provide insight into their general nature and the circumstances in which they occur are useful for developing preventive education. Further, an understanding of terminal ballistics is important for determining the appropriate clinical management of GSWs.

The extent of injury inflicted by a GSW is determined by the energy of the primary projectile, its dissipation in the tissue, and the generation of secondary projectiles following osseous injury. The kinetic energy of a bullet before impact is equal to half its mass multiplied by its velocity squared; the energy of a projectile thus increases exponentially with its velocity. In order to maximise mass (and minimise energy loss caused by air resistance), bullets are often made with pointed or rounded tips from metals with a high specific gravity, such as lead. The energy transferred to the tissue after impact is the difference in kinetic energy of the bullet as it enters and leaves the tissue. This difference is dependent on the bullet's diameter on impact and the density of the tissue. The more a bullet deforms or mushrooms on impact, the greater the amount of energy transferred to the tissue. ${ }^{7,8}$

High-velocity projectiles create large temporary cavities that fill with water vapour, causing tissue damage

\section{Abstract}

Objective: To examine the epidemiology of Americans shooting themselves in the foot.

Design: Data from the Firearm Injury Surveillance Study (1993-2010) collected using the National Electronic Injury Surveillance System were examined. Non-fatal firearm-related injuries were recorded during patients' initial emergency department visits.

Setting: United States hospital emergency departments, 1993-2010.

Participants: 69111 individuals admitted to US emergency departments after non-fatal firearm-related incidents.

Main outcome measure: Demographic and incident characteristics of patients presenting with self-inflicted gunshot wounds to the foot.

Results: Of the 6911 reported firearm-related injuries, 667 (1.0\%) were self-inflicted gunshot wounds to the foot. Of these, 597 of the patients (89.6\%) were men and 51.7\% (345) were aged between 15 and 34 years. Patients generally presented with puncture wounds ( 265 patients, 39.7\%), foreign bodies (164 patients, $24.6 \%$ ) and bruised egos. Those who shot themselves in the foot were significantly more likely than individuals with other firearm-related injuries to be male (odds ratio [OR], 1.28) and married $(\mathrm{OR}, 2.6)$. As the festive season approached, the number of incidents increased; November and December were peak months for shooting oneself in the foot.

Conclusions: The nature of and the circumstances surrounding self-inflicted gunshot wounds to the foot were unique when compared with other firearm-related injuries. Through the large-scale examination of the characteristics of these incidents, trends in the nature of Americans shooting themselves in the foot have been elucidated. Young married men are at particular risk of shooting themselves in the foot. Particular caution must be taken during the festive season to avoid being caught under the missing toe.

and wound contamination distal to the primary tract of the bullet. When a bullet collides with a dense object, such as bone, secondary missiles may be generated, the number of which increases with the velocity of the bullet. $^{9}$ These secondary missiles have less predictable trajectories and often do more soft tissue damage than the primary projectile. The velocity of the bullet is thus a primary determinant of tissue damage.

The foot has a number of anatomical and biomechanical features that make it unique in terms of GSW injury and management. The function of the foot depends on its ability to painlessly and efficiently transfer the energy generated by the leg muscles into locomotion. Unlike long bone and other joint injuries, low-velocity GSWs to the foot often result in significant morbidity, and are managed in the same manner as high-velocity injuries. The ratio of bone to soft tissue in the foot is high, with a particularly large number of articular surfaces. More than $80 \%$ of GSWs to the foot result in osseous injury, ${ }^{10}$ and such fractures frequently generate secondary projectiles that damage the densely populated neurovascular structures. The resulting inflammation and haemorrhage within the restricted fascial 
compartments of the foot predispose to compartment syndrome and other complications.

Management includes antibiotic therapy, operative debridement, bone stabilisation, revascularisation and soft tissue coverage. Low-velocity GSWs to the foot have traditionally been treated with intravenous antibiotic therapy for 1-5 days, ${ }^{11-14}$ followed by operative assessment of soft tissue contamination and irrigation. However, it is now generally accepted that both low- and high-velocity injuries require careful debridement of non-viable soft tissue and non-essential osseous fragments to prevent necrosis and wound infections. ${ }^{13-20}$ As mentioned earlier, the vast majority of GSWs to the foot involve intra-articular osseous injury. Even low-velocity injuries may require both internal and external percutaneous fixation of fractures to achieve adequate alignment. ${ }^{21}$ Highvelocity injuries are often allowed to heal by secondary intention, while others may require wound closure with myocutaneous flaps, skin grafting or, in extreme cases, amputation.

Until now there has been no largescale epidemiological examination of the injury characteristics and circumstance of GSWs to the foot. Given the anatomical and biomechanical features of the foot, these GSWs are unique in their presentation, and, while they have been studied on a case-by-case basis, ${ }^{22-24}$ the overarching trends of selfinflicted GSWs to the foot have not been investigated in a large sample. We undertook a large-scale epidemiological examination of Americans who had shot themselves in the foot.

\section{Methods}

\section{Study sample}

Using a stratified probability sample of all US hospitals with more than six beds that provide 24-hour accident and emergency services, the National Electronic Injury Surveillance System (NEISS) collected data for the period 1993-2010 as part of the Firearm Injury Surveillance Study. Based on the number of emergency department visits per year, hospitals were stratified as very large, large, medium or small. An additional stratum for children's hospitals was also used. Between 1993 and 1996, 91 emergency departments were included in the sample. An additional 10 hospitals were added between 1997 and 1999, with two dropouts between 2000 and 2002; 99 hospitals were included in the sampling frame 2002-2010.

\section{Data collection}

NEISS, the primary data collection body for the Consumer Product Safety Commission, was responsible for data collection. Data on initial emergency department visits that resulted from non-fatal firearmrelated injuries were extracted from the patients' medical records.

\section{Outcomes}

The characteristics of the patients and the conditions in which each sustained self-inflicted GSWs to the foot were the primary outcomes.

\section{Statistical analysis}

All statistical analysis was conducted in Stata 12 (StataCorp). Participants were identified as either generic firearm victims or patients who had a self-inflicted GSW to the foot. $\chi^{2}$ tests were used to compare the categorical variables of groups; ie, sex, age group, marital status, illicit drug use, involvement in criminal activities, weapon used, location of incident, and diagnosis. Logistic regression was undertaken for sex and marital status (married v not married).

\section{Results}

Of the 69111 reported firearm-related injuries, 667 (1.0\%) were self-inflicted GSWs to the foot. Individuals who shot themselves in the foot were typically men $(597,89.6 \%)$ aged 15-34 years $(345,51.7 \%)$. Incidents generally occurred in the home (381, $51.1 \%$ ), involved a handgun (208, $31.2 \%)$ or BB gun $(228,64.2 \%)$ while the individual was neither committing a crime nor under the influence of alcohol. Significant differences between individuals who shot themselves in the foot and those who had other firearm-related injuries with respect to $\operatorname{sex}\left(\chi^{2}=3.19, P=0.048\right)$, age group $\left(\chi^{2}=116.39, P<0.0001\right)$, marital status $\left(\chi^{2}=87.18, P<0.0001\right)$, illicit drug use $\left(\chi^{2}=24.49, P<0.0001\right)$, involvement in criminal activities $\left(\chi^{2}=330.79, \quad P<0.0001\right)$, weapon used $\left(\chi^{2}=457.56, P<0.0001\right)$, location of the incident $\left(\chi^{2}=571.16\right.$, $P<0.0001)$ and the physician's diagnosis $\left(\chi^{2}=273.18, P<0.0001\right)$ were noted (Box 1).

Logistic regression indicated that individuals who shot themselves in the foot were significantly more likely than individuals with other firearm-related injuries to be male (odds ratio $[\mathrm{OR}], 1.28 ; 95 \% \mathrm{CI}$, 1.0-1.7) and married (OR, 2.6; 95\% CI, 2.1-3.4).

Incidences of shooting oneself in the foot were most common in October, November and December (Box 2).

\section{Discussion}

Contrary to popular belief, incidents of Americans shooting themselves in the foot are relatively rare; the characteristics of these incidents, however, are unique. When these auto-foot shooters were compared with individuals who had sustained other firearm-related injuries, significant differences were noted in the demographic characteristics of the victim/assailant, weapon of choice, the circumstances of the incident, and the nature of the injury itself.

There are several limitations that must be acknowledged in the interpretation of these data. The study included only individuals who presented to US emergency departments with non-fatal firearm-related injuries, so that our comparisons cannot be generalised to the broader population. The primary source of most data was the individual who had shot themselves in the foot; while data about the injury were provided by health care professionals, information about the incident itself may be subject to self-report biases. A social desirability bias may have caused under-reporting of self-inflicted 


\begin{tabular}{|c|c|c|c|c|c|c|}
\hline & & \multicolumn{2}{|c|}{$\begin{array}{l}\text { Self-inflicted gunshot } \\
\text { wounds to the foot }\end{array}$} & \multicolumn{2}{|c|}{$\begin{array}{l}\text { Other firearm-related } \\
\text { injuries }\end{array}$} & \multirow[b]{2}{*}{$P^{*}$} \\
\hline & & Number & Percentage & Number & Percentage & \\
\hline Number ${ }^{\dagger}$ & & 667 & $1.0 \%$ & 68444 & $99.0 \%$ & \\
\hline \multicolumn{7}{|c|}{ Demographics } \\
\hline Sex (male) & & 597 & $89.6 \%$ & 59562 & $87.0 \%$ & 0.048 \\
\hline \multirow[t]{4}{*}{ Age } & $0-14$ years & 158 & $23.7 \%$ & 7691 & $11.2 \%$ & $<0.0001$ \\
\hline & 15-34 years & 345 & $51.7 \%$ & 45286 & $66.2 \%$ & \\
\hline & $35-54$ years & 134 & $20.1 \%$ & 12109 & $17.7 \%$ & \\
\hline & $\geq 55$ years & 30 & $4.5 \%$ & 2843 & $4.2 \%$ & \\
\hline \multirow[t]{6}{*}{ Marital status } & Married & 103 & $24.0 \%$ & 6117 & $11.6 \%$ & $<0.0001$ \\
\hline & Never married & 154 & $35.9 \%$ & 26826 & $51.0 \%$ & \\
\hline & Divorced or separated & 21 & $4.9 \%$ & 1262 & $2.4 \%$ & \\
\hline & Other & 8 & $1.6 \%$ & 635 & $1.2 \%$ & \\
\hline & Not stated & 143 & $33.3 \%$ & 17760 & $33.8 \%$ & \\
\hline & & \multicolumn{2}{|c|}{ The incident } & & & \\
\hline Drugs involved & & 11 & $1.7 \%$ & 1644 & $2.4 \%$ & $<0.0001$ \\
\hline Crime involved & & 5 & $1.0 \%$ & 11680 & $17.1 \%$ & $<0.0001$ \\
\hline \multirow[t]{5}{*}{ Weapon } & Handgun & 208 & $31.2 \%$ & 19002 & $27.8 \%$ & $<0.0001$ \\
\hline & Rifle & 80 & $12.0 \%$ & 3169 & $4.6 \%$ & \\
\hline & Shotgun & 60 & $9.0 \%$ & 2697 & $3.9 \%$ & \\
\hline & BB gun & 228 & $64.2 \%$ & 10094 & $14.8 \%$ & \\
\hline & Unknown & 91 & $13.6 \%$ & 33482 & $48.9 \%$ & \\
\hline \multirow[t]{10}{*}{ Location } & Home & 381 & $57.1 \%$ & 14661 & $21.4 \%$ & $<0.0001$ \\
\hline & Farm & 5 & $0.8 \%$ & 109 & $0.2 \%$ & \\
\hline & Apartment or condominium & 1 & $0.2 \%$ & 75 & $0.1 \%$ & \\
\hline & Street or highway & 12 & $1.8 \%$ & 14049 & $20.5 \%$ & \\
\hline & Other public area & 24 & $3.6 \%$ & 7500 & $11.0 \%$ & \\
\hline & Mobile home & 1 & $0.2 \%$ & 112 & $0.2 \%$ & \\
\hline & School & 1 & $1.0 \%$ & 276 & $0.4 \%$ & \\
\hline & Recreational area & 18 & $18.0 \%$ & 1140 & $1.7 \%$ & \\
\hline & Unknown & 224 & $33.6 \%$ & 30473 & $44.5 \%$ & \\
\hline & & \multicolumn{2}{|c|}{ The injury } & & & \\
\hline \multirow[t]{8}{*}{ Diagnosis } & Amputation & 2 & $0.3 \%$ & 128 & $0.2 \%$ & $<0.0001$ \\
\hline & Contusion or abrasion & 7 & $1.1 \%$ & 3936 & $5.8 \%$ & \\
\hline & Foreign body & 164 & $24.6 \%$ & 7289 & $10.7 \%$ & \\
\hline & Fracture & 75 & $11.2 \%$ & 3738 & $5.5 \%$ & \\
\hline & Laceration & 25 & $3.8 \%$ & 7818 & $11.4 \%$ & \\
\hline & Puncture & 265 & $39.7 \%$ & 24317 & $35.5 \%$ & \\
\hline & Avulsion & 1 & $0.2 \%$ & 99 & $0.1 \%$ & \\
\hline & Other & 128 & $19.2 \%$ & 16680 & $24.4 \%$ & \\
\hline
\end{tabular}

* Self-inflicted wounds $v$ other firearm-related wounds. $\uparrow$ Number of injuries and percentage of all firearm-related injuries. All other percentages in the table are column percentages.

wounds, as individuals who shoot themselves in the foot may not be entirely forthcoming about the nature and cause of their injuries.
Never-married men between the ages of 15 and 34 years were the most common perpetrators of self-inflicted GSWs to the foot. Due to the disproportionate number of males who possess firearms, it is to be expected that the prevalence of these injuries would be higher among men. 
2 Gunshot wounds in the United States, by month; expressed as a percentage of all foot- or non-foot-related incidents

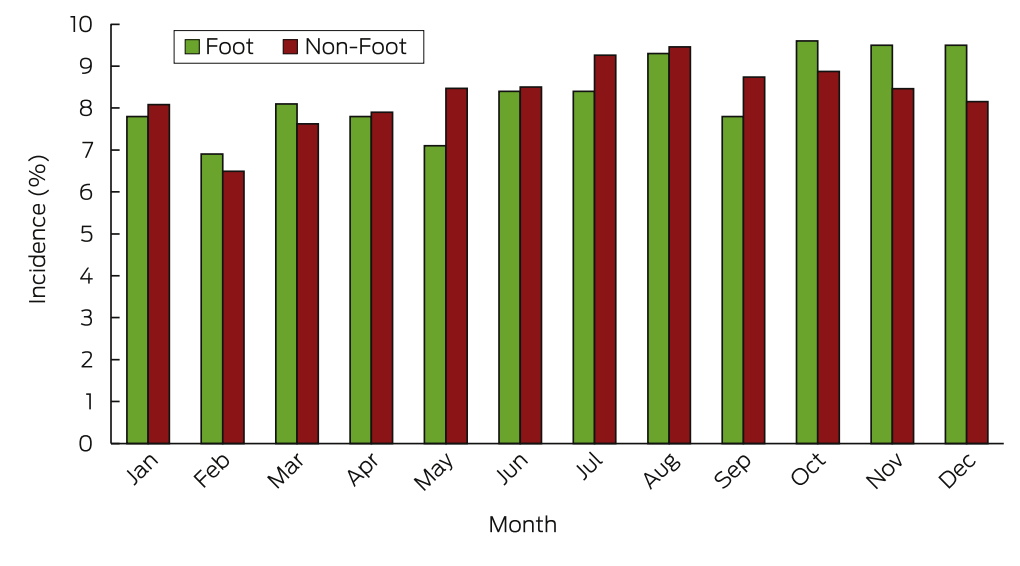

Of interest, however, was the strength of the relationship between being married and shooting oneself in the foot when compared with the odds of other firearms-related injuries and non-married self-saboteurs. These results are consistent with anecdotal reports from disgruntled spouses and depictions of married men in the mainstream media, such as sitcoms and reality television programs. However, due to the nature of our data, evidence-based generalisations to the broader American population cannot conclusively be made.

Shooting oneself in the foot was extremely uncommon during the commission of a crime or while under the influence of drugs; only five individuals shot themselves in the foot while committing a crime. Given that inhibitions are reduced and cognitive capacity diminished by drug use, it is a somewhat counterintuitive finding that the association of illicit drug use with shooting one's foot was not stronger. An investigation into the relationship between alcohol use and self-inflicted podiatric injuries is an area for future research, given the ease of access to alcohol and the prevalence of alcohol use in other firearm-related injuries.

There was a strong positive correlation between the month of the year and the number of self-inflicted GSWs to the foot; a disproportionate number of incidents occurred in October, November and December. It is notable that these trends were much stronger than for other firearmrelated incidents, with a relatively constant number of these incidents throughout the year.

The epidemiology of firearm-related podiatric trauma has been neglected until now; to our knowledge, ours is the first large-scale epidemiological investigation of GSWs to the foot or of self-inflicted GSWs to the foot. Given the anatomical and biomechanical features of the foot, the nature of the wounds caused by GSWs is unique. A major epidemiological study is required to examine overarching trends in the circumstances and scenarios in which these events occur. Although it may not be possible to prevent Americans from shooting themselves in the foot, large-scale investigations of the nature of these incidents provides invaluable information for those at greatest risk. Particular caution must be taken during the festive season if one is to avoid being caught under the missing toe.

Acknowledgements: We thank Nicola Batrick for her comments on an earlier draft of this manuscript.

Competing interests: No relevant disclosures.

(c) 2015 AMPCo Pty Ltd. Produced with Elsevier B.V. All rights reserved.

References are available online at www.mja.com.au. 
1 Small Arms Survey. Small arms survey 2007: guns and the city. Cambridge, NY: Cambridge University Press, 2007.

2 Ikeda RM, Gorwitz R, James SP, et al. Fatal firearm injuries in the United States 1962-1994. Atlanta: Centers for Disease Control and Prevention, National Center for Injury Prevention and Control, 1997.

3 US Centers for Disease Control and Prevention. WISQARS [database]. http://www.cdc.gov/injury/wisqars/ index.html (accessed Oct 2015).

4 Weaver LD, Hansraj KK, Idusuyi OB, et al. Gunshot wound injuries. Frequency and cost analyses in south central Los Angeles. Orthop Clin North Am 1995; 26: 1-7.

5 Hakanson R, Nussman D, Gorman RA, et al. Gunshot fractures: a medical, social, and economic analysis. Orthopedics 1994; 17: 519-523.

6 Levy RS, Hebert CK, Munn BG, Barrack RL. Drug and alcohol use in orthopedic trauma patients: a prospective study. J Orthop Trauma 1996; 10: 21-27.

7 McSwain NE. Ballistics. In: Ivatury RR, Cayten CG, editors. The textbook of penetrating trauma. Baltimore: Williams \& Wilkins, 1996; 108.

8 Barach E, Tomlanovich M, Nowak R. Ballistics - a pathophysiologic examination of the wounding mechanisms of firearms. 2. J Trauma 1986; 26: 374-383.
9 Swan K, Swan RC. Gunshot wounds: pathophysiology and management. Chicago: Year Book Medical Publishers, 1989.

10 Howland WS, Ritchey SJ. Gunshot fractures in civilian practice. An evaluation of the results of limited surgical treatment. J Bone Joint Surg Am 1971; 53: 47-55.

1 Boucree JB, Gabriel RA, Lezine-Hanna JT. Gunshot wounds to the foot. Orthop Clin North Am 1995; 26: 191-197.

12 Sergi AR, Acello AN. Gunshot wounds to the foot and ankle. Clin Podiatr Med Surg 1995; 12: 689-702.

13 Gustilo R, Anderson J. Prevention of infection in the treatment of one thousand and twenty-five open fractures of long bones. Retrospective and prospective analysis. J Bone Joint Surg 1976; 58: 453-458.

14 Gustilo RB, Merkow RL, Templeman D. The management of open fractures. J Bone Joint Surg Am 1990; 72: 299-304.

15 Geissler WB, Teasedall RD, Tomasin JD, Hughes JL. Management of low velocity gunshot-induced fractures. J Orthop Trauma 1990; 4: 39-41.

16 Hoekstra SM, Bender JS, Levison MA. The management of large soft-tissue defects following close-range shotgun injury. J Trauma 1990; 30: 1489-1493.
17 Morgan MM, Spencer AD, Hershey FB. Debridement of civilian gunshot wounds of soft tissue. J Trauma 1961; 1: 354-360.

18 Thoresby FP, Darlow HM. The mechanisms of primary infection of bullet wounds. Br J Surg 1967; 54: 359-361.

19 Swiontowski MF. Criteria for bone debridement in massive lower limb trauma. Clin Orthop Rel Res 1989; 243: 41-47.

20 Patzakis MJ, Wilkins J. Factors influencing infection rate in open fracture wounds. Clin Orthop Relat Res 1989; (243): 36-40.

21 Molinari RW, Yang EC, Strauss E, Einhorn TA. Timing of internal fixation in low-velocity extremity gunshot fractures. Contemp Orthop 1994; 29 : 335-339.

22 Dayton PD, Risser J. Handgun injuries to the foot: treatment of low-velocity, high-energy wound types. $J$ Foot Surg 1990; 29: 309-317.

23 Newman P, Hugar DW. Gunshot wound to the foot: early management and pathophysiology of projectile wounds. J Foot Surg 1984; 23: 203-206.

24 Verheyden CN, McLaughlin B, Law C, et al. Through-and-through gunshot wounds to the foot: the "Fearless Fosdick" injury. Ann Plast Surg 2005; 55: 474-478. 